Est Ag 52 (2017) 241-270

\title{
La iniciación en los inicios del cristianismo (sS. I-II)
}

RESUMEN: Desde el principio la incorporación a las comunidades cristianas de nuevos miembros se realizaba mediante un camino iniciático. A pesar del diverso origen de los grupos y la pluralidad de contextos culturales, se mantendrán como elementos centrales un rito bautismal y la posterior agregación plena a la comunidad eclesial por la participación en el banquete eucarístico. El presente trabajo trata de aproximarse a las características rituales de ese proceso de iniciación en su desarrollo durante los dos primeros siglos. Las fuentes disponibles, no permiten una reconstrucción pormenorizada del mismo en ese período, pero su estudio descubre los factores que posibilitarán la génesis de una praxis organizada a partir del s. III. Sirvan estas páginas como memoria agradecida al prof. Senén Vidal.

Palabras Clave: Ritualidad religiosa - Iniciación cristiana - Orígenes del cristianismo - Sacramentos de Iniciación.

ABSTRACT: From the beginning, joining the Christian communities required new members to get into an initiation path. Though the various backgrounds of the groups and the plurality of cultural contexts, some central elements, like a baptismal rite or the subsequent fully aggregation to the ecclesial community by sharing the eucharistic meal, will remain. This paper tries to approach to the ritual performance of the initiation process' development along the first two centuries of Christianity. The sources available do not show a detail reconstruction of the topic in this period, but this searching finds out the factors that will drive to an organized praxis from the IIIth century onwards. May these pages be a grateful remenbrance of prof. Senén Vidal.

Key Words: Religious Ritualism - Christian Initiation - Origins of Christianity Sacraments of Initiation. 
Los ritos son un elemento fundamental en la adquisición de la propia identidad y un instrumento necesario para dotar de sentido de pertenencia a los grupos humanos. "Marcan los límites entre los de dentro y los de fuera, estructuran los tiempos y espacios dentro de los cuales se vive esta identidad, sirven de renovación de las experiencias fundantes en el ámbito religioso, refuerzan las creencias compartidas y actúan como un importante medio de socialización"1.

El cristianismo nace en el ambiente religioso judío y se desarrolla en el romano-helenista. Por eso no debería extrañar que estos dos ámbitos culturales hayan ejercido un influjo notable en la praxis de iniciación de la Iglesia primitiva. Sin embargo, tanto respecto a los ritos de iniciación judíos como a los ritos de iniciación en los misterios paganos, la iniciación cristiana va a presentar unos rasgos que le dan una especificidad propia ${ }^{2}$. En relación con el judaísmo, la nota diferenciadora fundamental del proceso iniciático cristiano está representada por la progresiva desaparición de ciertas prácticas judías (circuncisión), conservadas todavía en las comunidades judaizantes, con la apertura universalista a la gentilidad. Más que de una ruptura hay que hablar de una superación y de una comprensión nueva de algunos ritos comunes (baños de purificación, comidas sagradas), reinterpretados a partir de la experiencia pascual.

En el marco de las prácticas religiosas ${ }^{3}$ cristianas, el presente estudio pretende rastrear los elementos rituales que fueron conformando la praxis iniciática durante los dos primeros siglos del cristianismo. Por consiguiente, el trabajo se centra solamente en la génesis del aspecto litúrgicocelebrativo de la iniciación, abordando sólo indirectamente los aspectos doctrinales y morales de la instrucción que también formaban parte integrante del proceso de iniciación. La exposición desarrolla la temática en tres apartados, siguiendo un método diacrónico: el movimiento de Jesús y la primera generación cristiana (hasta el 70), la generación apostólica (70-110) y los testimonios subapostólicos (s. II).

\footnotetext{
${ }^{1}$ Rivas, Fernando, "El nacimiento de la Gran Iglesia", en Aguirre, Rafael (eds.), Así empezó el cristianismo, Verbo Divino, Estella 2010, 435.

2 Cf. Eliade, Mircea, Iniciaciones místicas, Taurus, Madrid 1975, 196-203.

3 En todas las tradiciones religiosas funciona un sistema de mediaciones de la experiencia religiosa. Esas mediaciones son de tres tipos: doctrinales (creencias), morales (preceptos) y prácticas (acciones). Entre las prácticas religiosas, a su vez, se distinguen dos grupos: los actos de servicio y los actos de culto. A este último grupo pertenecen los ritos religiosos.
} 


\section{EL MOVIMIENTO DE JESÚS Y LA PRIMERA GENERACIÓN CRISTIANA}

\section{La praxis iniciática en el judaísmo}

Los ritos de purificación por medio del agua son comunes a muchas culturas y religiones. También la religión de Israel, en base a las leyes de pureza ritual, prescribía distintos tipos de abluciones y baños según las circunstancias y los destinatarios (cf. Lv 14,5-6.50-52; Nm 19,13.20-21). A comienzos de la era cristiana, con los fariseos como "maestros de santidad", aumentaron considerablemente los ritos de purificación y, además de las abluciones prescritas por la ley, se pueden distinguir cuatro clases principales de baños rituales: el de los rabinos, el de los prosélitos, los de Qumrán y el de Juan. El instituido por las escuelas rabínicas era una forma de ablución, propia de los maestros al terminar la enseñanza. Nos interesa más considerar las otras tres modalidades que tienen propiamente el carácter de bautismo 4 .

La circuncisión es el rito de iniciación por excelencia del judaísmo. Según la ley tenía lugar a los ocho días del nacimiento (Gn 17,12; cf. Ex $12,48)$, era el signo de pertenencia al pueblo elegido y conllevaba el compromiso de cumplir la ley de Moisés. Jesús fue sometido a este rito (cf. Lc 2,21). El grupo judeocristiano de Jerusalén, liderado por Santiago, el hermano del Señor, siguió practicándolo. A menudo se les identifica precisamente como "los de la circuncisión" (Gal 2,12; Hch 10,45; Hch 11,2). Además de la circuncisión, la literatura rabínica menciona como rito de ingreso en el judaísmo el "baño de los prosélitos". Formaba parte de un rito de iniciación del tardo-judaísmo -quizás practicado ya a finales del s. I p.C.- que consistía en una sola inmersión purificadora. A diferencia de la circuncisión, se sometían a él también las mujeres. Este baño de inmersión se practicaba con los adultos extranjeros que pasaban al judaísmo, después de la circuncisión en el caso de los varones. Sus efectos eran la definitiva incorporación al pueblo de Israel y la liberación de toda impureza. Para el NT, el bautismo cristiano tiene como paralelo judío explícito la circuncisión (cf. Col 2,11-12) y no aquel bautismo. Por consiguiente, incluso suponiendo que pudiera llegar a datarse algún tipo de influencia, hay una diferencia fundamental entre ambos ritos bautismales: mientras

4 Cf. LohfinK, Gerhard, "Der Ursprung der christlichen Taufe", en Theologische Quartalschrift 156 (1976) 35-54; LÉGASSE, Simon, "Baptême juif des prosélytes et baptême chrétien", en Bulletin de littérature ecclésiastique 77 (1978) 3-40; BARTH, Gerhard, El bautismo en el tiempo del cristianismo primitivo (=BEB 60), Sígueme, Salamanca 1986, 25-40 y 161-162; MeIER, John P., Un judío marginal. Nueva visión del Jesús histórico. II/I: Juan y Jesús. El reino de Dios, Verbo Divino ${ }^{3}$, Estella 2001, 55 y 84-88. 
el prosélito se baña para purificarse, el catecúmeno es bautizado. Es decir, el baño de los prosélitos era un autobautismo, pues a los testigos presentes, nunca se les llama bautizantes o bautistas.

Los ritos de lavatorio de la comunidad de Qumrán hay que situarlos en el contexto del movimiento baptista (s. II a.C. - s. IV d.C.) difundido por el próximo oriente. Según la "Regla de la comunidad", entre los grupos de esenios el proceso para la admisión de nuevos miembros a la secta comportaba la praxis de varios baños rituales (cf. 1QS 3,4-12; 5,13-14). El período iniciático constaba de una preparación previa y dos años de "noviciado". El paso de una etapa a otra estaba regulado por actos litúrgicos acompañados de ritos de purificación por agua. Sólo el novicio admitido al segundo año podía participar del mismo tipo de ritos lustrales que los miembros de pleno derecho. La ceremonia de admisión de nuevos miembros tenía lugar anualmente con ocasión de la fiesta de renovación de la alianza (Pentecostés) y comportaba la recepción de los "votos", la recitación de fórmulas de bendición y maldición, y una celebración bautismal. La inmersión se realizaba en piscinas o en el Jordán. En la secta de Qumrán el baño ritual se repetía periódicamente durante todo el tiempo de pertenencia a la comunidad para indicar el esfuerzo permanente de purificación de la contaminación del mundo.

Según la tradición sinóptica, en el desierto de Judea Juan Bautista predicaba "un bautismo de conversión para la remisión de los pecados" (Mc 1,4; Q 3,3). Pero no se limitaba a predicarlo, también lo administraba en la cuenca oriental del Jordán, de ahí que recibiera el apelativo de "Bautista" - un sobrenombre que no le aplica el Cuarto evangelio-. Mateo añade, además, la conexión radical del bautismo de Juan con la obra mesiánica de Jesús. El bautismo de agua es el rito que acompaña a la proclamación de la venida del Mesías (cf. Mt 3,11). El rey Herodes Antipas (+39 p.C) mandó arrestar a Juan y ordenó que lo decapitaran en la cárcel (cf. Mc 6,14-29 par) hacia el año 29 de la era cristiana. Entre las fuentes no cristianas sobre el Bautista la única fiable es una alusión de Flavio Josefo en Antigüedades judías. Se trata de un excursus después de narrar la derrota del ejército de Antipas por el rey nabateo Aretas IV (36 p.C) y que desembocó en su destierro en tiempos del emperador Calígula. Este testimonio confirma que el bautismo de Juan tuvo un carácter profético5. $^{5}$ El simbolismo de este rito bautismal tiene que ver con la

5 "Pero, a algunos judíos les parecía que el ejército de Herodes [Antipas] había sido destruido por Dios... para vengar la muerte de Juan, llamado Bautista. De hecho, Herodes lo había mandado matar, a él, un hombre de bien, que exhortaba a los judíos que se ejercitaban en la virtud y practicaban la justicia entre ellos y la piedad hacia Dios, a reunirse para un baño. Y la inmersión le parecía aceptable si servía no para el perdón de ciertas 
inmersión y con el elemento del agua. La inmersión indica la muerte que supone el arrepentimiento y un "nuevo nacimiento". El "agua viva" del Jordán es el símbolo de la bendición divina (cf. Is 35,1-7; 41,18; Jer 3,18). No era un "rito de iniciación" para crear un grupo (J. Meier). Representaba el nuevo ingreso del Israel renovado en la tierra prometida. "Tenía así un carácter iniciático. Pero no en el sentido de que marcara el ingreso una comunidad especial dentro del pueblo"6.

Aunque desconocemos los detalles precisos, el bautismo de Juan aparece como un gesto profético con tres características principales: se trata de un baño de inmersión único, recibido del propio Bautista (heterobautismo) y de carácter moral (conversión) y escatológico (nuevo pueblo de Dios). Se distingue así de las otras prácticas judías de baños rituales a los que nos hemos referido. Aquéllas eran formas de autobautismo, mientras que el Bautista ejerce un rol activo y personal. Las fuentes no permiten asegurar que el baño de los prosélitos se practicara en tiempos de Juan. En todo caso estaba destinado solamente a los extranjeros convertidos a la fe de Israel por la circuncisión. En cambio, el bautismo de Juan se ofrece a todos, no sólo a los conversos. En cuanto a los ritos de purificación de la comunidad de Qumrán, el bautismo de Juan es un acto único no reiterable, de acuerdo con lo que significa; los lavatorios de Qumrán, en cambio, multiplicaban los baños rituales. En segundo lugar, Juan bautizaba a todo el que venía a él, con una voluntad de reforma abierta a todo el pueblo: no marcaba la entrada en un grupo restringido -aunque algunos se convirtieran en sus discípulos-; la comunidad de Qumrán reservaba el baño ritual a los miembros de la secta (candidatos o ya iniciados). Además, el bautismo de Juan es el signo del perdón de Dios consiguiente a la conversión; los de la secta, aunque exhortan al cambio interior, tienen como finalidad sobre todo la pureza ritual externa.

Jesús pertenece al grupo de los bautizados por Juan (ca. 28): se somete personalmente a ese bautismo (cf. Mc 1,9-11; Mt 3,13-17; Lc 3, 21-

culpas, sino para la pureza del cuerpo, después de que el alma hubiera sido ya completamente purificada por la justicia. Pero como otros se reunían en torno a él..., Herodes temía que su extraordinaria fuerza de persuasión provocase alguna sedición, porque parecían dispuestos a todo siguiendo el consejo de Juan. Por eso prefirió capturarlo antes de que, a causa suya, ocurriese algún imprevisto, para no tener que arrepentirse después, si hubiera nacido un movimiento, de encontrarse metido en una situación difícil. Por eso, Juan, enviado prisionero a Maqueronte, la fortaleza de la que ya hemos hablado, a causa del temor de Herodes, allí lo hizo morir. En opinión de los judíos la destrucción había caído sobre el ejército para vengarlo, queriendo Dios castigar así a Herodes" (Flavio Josefo, Antigüedades judías XVIII, 116-119).

6 VIDAL, Senén. Iniciación a Jesús de Nazaret, Sal Terrae, Santander 2014, 40. 
22; Jn 1,32-34) y denuncia el rechazo del bautismo de Juan por los fariseos y los doctores de la ley (cf. Mt 21,32; Lc 7,29-30). Curiosamente durante los tres primeros siglos de la era cristiana no se celebra el nacimiento de Jesús. En cambio, se celebra ya la fiesta del bautismo de Jesús como el momento de su "nacimiento" a la vida pública. El bautismo de Juan da un carácter nuevo a la orientación que desde entonces adoptará la vida y la misión de Jesús. Los ebionitas verán en este acontecimiento el momento de la divinización de su humanidad. Sin llegar a este extremo, la fe primitiva ha descubierto ahí la manifestación de su mesianismo. Aunque el origen del bautismo cristiano no se explica satisfactoriamente sólo en referencia al bautismo de Jesús por Juan, ello no quiere decir que este hecho no contribuyera de modo decisivo al nacimiento de la praxis cristiana de bautizar. Consta que el cristianismo primitivo, tras la Pascua, comenzó a incorporar a sus nuevos miembros mediante un rito bautismal, y que en ese bautismo adoptó las características esenciales del bautismo de Juan. Pero antes de abordar ese tema, vamos a tratar de recuperar los elementos iniciáticos del discipulado de Jesús a partir de las fuentes evangélicas.

\section{La entrada en el movimiento de Jesús}

¿Bautizó Jesús? En este punto parece pertinente esta pregunta. Ciertos pasajes joánicos, en polémica con los discípulos de Juan, parecen sugerirlo (cf. Jn 3,22-26; Jn 4,1-3) -aunque no sin cierta ambigüedad (cf. Jn 4,2)-. Habiendo recibido él mismo el bautismo de Juan, Jesús no sólo acogió inicialmente la misión del Bautista, sino que permaneció en su compañía y posiblemente colaboró con él en la actividad bautismal7. Pero parece improbable que Jesús bautizara durante su propio ministerio público ${ }^{8}$. Al respecto, es contundente que Pablo, que se refiere ya al bautismo como una práctica de la comunidad cristiana anterior a él, nunca lo ponga en relación con un gesto de Jesús como hace expresamente para la eucaristía (cf. 1Cor 11,23-25). ¿Cómo era entonces el camino a seguir para ingresar en su grupo? Los evangelios distinguen tres círculos concéntricos de seguidores de Jesús. El más externo y amplio está formado

7 Esta conclusión es compartida mayoritariamente por los exegetas católicos (S. Légasse, J. Gnilka, J. Meier, S. Vidal), con la excepción de G. Lohfink. En sentido contrario los protestantes G. Barth y J. Roloff, entre otros, sostienen que Jesús no bautizó.

8 En su misión autónoma por los poblados de Galilea, abandonando el desierto, la comensalía abierta se convertirá en su principal signo iniciático. Cf. S. VIDAL, Iniciación a Jesús de Nazaret, 63-71. 
por las muchedumbres que lo siguen, espontánea y esporádicamente, atraídas por sus milagros y sus enseñanzas. El círculo intermedio lo componen aquellos discípulos que lo siguen acogiéndole a él y a los Doce en sus casas y apoyándole en su misión, sin por ello abandonar su hogar y sus ocupaciones habituales. Finalmente, el círculo más interior y restringido, el de los Doce, lo forman los que habiendo sido llamados por Jesús y dejándolo todo, al menos temporalmente, le acompañan en su misión itinerante?.

Para comprender la relación de Jesús con ese último grupo íntimo de discípulos galileos es preciso aproximarse al contexto de los modos de relación discipular existentes en el judaísmo. En la historia de Israel el discipulado se desarrolla en dos ámbitos principales: el sapiencial (cf. Prov 2,1) y el profético (cf. Is 8,16). En los círculos de sabios la relación maestro-discípulo tenía como finalidad la transmisión de unos conocimientos adquiridos a partir de la experiencia. En cambio, en los círculos proféticos el discipulado estaba centrado en la adhesión personal al nabi y al mensaje divino del que era portavoz. Estas dos formas básicas de discipulado perviven en el s. I: la sapiencial, entre los fariseos y escribas; la profética, en los movimientos renovadores como el de Juan Bautista. La relación discipular en el grupo de los Doce posee rasgos de ambas, pero constituye una experiencia singular.

Hay que tener en cuenta que la ambientación actual de los evangelios es obra de la segunda generación de discípulos y que no resulta fácil reconstruir la experiencia original del discipulado de Jesús. Sin embargo, como ha mostrado S. Guijarro, en las tradiciones de que disponemos es posible constatar un proceso común en tres pasos que se inicia con la llamada del Maestro, continúa con una instrucción sobre el estilo de vida del discípulo y culmina con la incorporación a la propia misión de Jesús ${ }^{10}$.

En los evangelios encontramos tres tipos de relato vocacional: el marcano, el joánico y el de otras tradiciones. Mientras que Marcos -a quien siguen los otros Sinópticos- sitúa la vocación de los primeros discípulos junto al mar de Galilea, después del arresto del Bautista y al comienzo del ministerio público de Jesús (cf. Mc 1,14-15), el evangelio de Juan la sitúa en Judea y durante la misión de Juan Bautista (Jn 1,35-51). Por último, otras tradiciones (cf. Lc 9,57-62; Mc 10,21-22) conservan también la memoria de llamadas de Jesús no sólo al comienzo, sino también en otras ocasiones posteriores de su actividad pública. Estos datos -aun-

${ }^{9}$ Cf. MeIER, John P., Un judío marginal. Nueva visión del Jesús histórico. III: Compañeros y competidores, Verbo Divino, Estella 2003, 43-214.

10 Cf. Guijarro, Santiago, Jesús y el comienzo de los evangelios, Verbo Divino, Estella 2006, 87-101. 
que aparentemente contradictorios- nos permiten reconstruir los rasgos que caracterizan la llamada de Jesús.

En primer lugar, destaca la autoridad del Maestro. Jesús es quien toma la iniciativa, ocupando el lugar de Yhwh de los relatos vocacionales veterotestamentarios (p.e. Ex 3,1-4,14; Is 6). Además, Jesús pide una adhesión incondicional a su persona. Esto significa que la vocación de los discípulos debe entenderse en el marco de la singular relación de Jesús con Dios. En segundo lugar, es Jesús mismo quien elige a los Doce (cf. Mc 3,13). A diferencia de los otros círculos de discípulos, en los que a veces la iniciativa de unirse al movimiento de Jesús parte de los mismos que han sido curados o exorcizados (cf. Mc 5,18) o de quienes se acercan a Él con el deseo de seguirle (Q 9,57-62), el grupo de los Doce fue escogido personal y directamente por voluntad de Jesús ${ }^{11}$. En tercer lugar, el Maestro impuso a los discípulos unas condiciones extremadamente duras para pasar a pertenecer al grupo. La más gravosa, sin duda, la ruptura con la casa, que era la principal institución social del mundo grecorromano $^{12}$. Ese es el contexto en el que hay que valorar los cambios -vitales y de estatus social- que se producen en la vida de los llamados por Jesús (dejar las redes, la barca, abandonar al padre, levantarse del telonio...). Por último, en cuarto lugar, la llamada de Jesús tiene un doble objetivo concreto: "para que estuvieran con Él y para enviarlos a predicar" (Mc 3,14). Se establece una nueva relación con el Maestro que implica no sólo el aprendizaje de una doctrina, sino la iniciación en su estilo de vida y la identificación personal con su destino. Esa identidad nueva es, además, la condición para incorporarse a la misión de Jesús de anunciar y hacer presente el reinado de Dios.

Los evangelios presentan a los Doce con muchos contrastes. En Mar$\cos$-que subraya sus rasgos negativos- aparecen como personajes ambiguos, que comienzan respondiendo a la llamada de Jesús (cf. Mc 1,16-20) y terminan negándole y abandonándole (cf. Mc 14,43-47). En cambio, Mateo los presenta más positivamente como modelos de fe (cf. Mt 14,28-31). Por su parte, Lucas destaca sobre todo la radicalidad de su seguimiento (cf. Lc 9,57-62;18,18-34). Por último, es significativo que Juan solamente se refie-

${ }^{11}$ Esta apreciación contradice el lugar común de que Jesús llamó a unos pobres pescadores incultos de Galilea. A propósito, es significativo que ninguno de los Doce fuera campesino. Es cierto que el movimiento iniciado por Jesús en Galilea, desde el punto de vista sociológico, fue un movimiento campesino de masas. Ahora bien, cuando ese movimiento entra en crisis, fueron los Doce y el grupo de simpatizantes los que continuaron el proyecto de Jesús.

12 Es el tema de la tesis doctoral de S. Guijarro. Sin embargo, según él "en los relatos de vocación no queda claro si la ruptura con la familia fue una exigencia o una consecuencia de la llamada de Jesús" (GuiJARro, Jesús, 93 nota 81). 
ra una vez al grupo de los Doce (cf. Jn 6,70-71) y que el modelo del grupo no sea Pedro sino el Discípulo Amado (cf. Jn 20,3-9.20-21). Detrás de estas imágenes tan variadas se puede recuperar el conjunto de rasgos propios que caracterizan el estilo de vida del discípulo de Jesús. El discipulado significa seguimiento de Jesús (cf. Mc 1,18; Mc 10,28; Lc 9,60). Y seguir al Maestro consiste, en primer lugar, en "ir detrás de Él" (Mc 1,17.20) para aprender no sólo de sus palabras, sino también de su actuación. En segundo lugar, consiste en acompañarle compartiendo su forma de vida. Y por último, consiste también en estar dispuesto a asumir su destino. El discipulado de Jesús, a diferencia del de otros maestros, supone una convivencia continuada. El primer aspecto implica "ver y oír", como recoge una de las bienaventuranzas (cf. Lc 10,23-24). El segundo aspecto supone compartir ciertos posicionamientos críticos de Jesús que resultaron provocativos y causaron rechazo: el conflicto con la propia familia (cf. Mc 3,20-21.31-35), su itinerancia sin domicilio fijo (cf. Lc 9,58 par), la comensalía con pecadores y gente de mala fama (cf. Mc 2,15-17; Lc 7,34), la denuncia del ritualismo de ciertas normas y prácticas religiosas (cf. Mc 2,18-20; Mc 2,23-28; Mc 7,1-15). Finalmente, el tercer aspecto de la vinculación del grupo de los Doce con Jesús es una consecuencia del anterior: vivir como Jesús, al final, llevó a los discípulos a correr la misma suerte de su Maestro. Esto supone, por un lado, participar desde ahora en la recompensa por permanecer fieles a Jesús (cf. Mt 19,27-30), pero implica también, por otro, compartir su mismo destino de persecución y de muerte (cf. Mc 8,34-38; Mc 9,35-37 y Mc 10,41-45).

El tiempo pasado por los Doce con Jesús, compartiendo su vida y su destino, fue una etapa de preparación iniciática para incorporarse a su misión de anunciar y hacer presente el reinado de Dios. El envío de los discípulos que aparece en los evangelios refleja ya la comprensión pascual de la tarea misionera de los evangelistas, pero conserva una antigua tradición remontable a Jesús. Está recogida en dos colecciones de dichos independientes (Mc 6,7-13 y Q 10,1-12) que, no obstante, contienen varios elementos comunes. El vocabulario que Jesús emplea para referirse a sus enviados no procede de los oficios religiosos o civiles de la época, sino de oficios comunes. Los discípulos son llamados para ser "pescadores" (Mc 1,17), "jornaleros" (Mt 9,38) o "pastores" (Mt 9,36). El hecho de que los dos primeros términos caigan en desuso en las comunidades cristianas de la primera y segunda generación, y que el tercero deje de evocar un ministerio itinerante para designar un oficio estable (cf. Hch 20,28; 1Pe 5,1-4), induce a pensar que Jesús no concibió la misión inicial de los Doce como un quehacer organizado y estable, sino más bien como un servicio temporal. Otro elemento importante para entender la concepción jesuánica de la misión es identificar a sus destinatarios. El grupo de los Doce representa la restauración de 
Israel -las doce tribus-. Y dentro de Israel, los destinatarios privilegiados de dicha misión fueron los sectores sociales excluidos y marginales. Es decir, implicaba ya germinalmente la ruptura de las fronteras sociales. Dicho de otro modo, la misión de Jesús, a la que se incorporan los Doce, tuvo un "carácter inclusivo" que facilitará después a los primeros cristianos la acogida de los no judíos en sus comunidades. Las instrucciones del Maestro para la misión de los Doce hacen referencia a tres actuaciones concretas que eran símbolos de la presencia activa del reinado de Dios: expulsar demonios, curar enfermos y compartir la mesa. Por eso, los exorcismos, las curaciones y la comensalía abierta serán también prácticas rituales de los discípulos de Jesús.

En conclusión, se puede sostener que el proceso seguido para pertenecer al movimiento de Jesús tiene significativas semejanzas con los ritos de paso de transformación de estatus ${ }^{13}$. Estos ritos siguen el esquema común de la liminalidad en tres etapas. La primera, de separación, consiste en una ruptura con la situación y las relaciones precedentes (casa, ocupación). Es lo que observamos en el momento preliminar de la llamada. La segunda, de margen o prueba, es el estado intermedio en que los que participan en el proceso de iniciación (instrucciones, aprendizajes) forman una comunidad igualitaria con el Maestro. Esta etapa coincide con la fase liminar del seguimiento, compartiendo la vida, las enseñanzas y la actuación de Jesús. Finalmente, la última etapa es la agregación. En ella los que han afrontado y superado el tiempo de prueba, retornan al propio ambiente, pero ahora revestidos de una nueva condición. Corresponde al momento postliminar del envío misionero. Cuando Jesús los envió no eran ya "pescadores", sino "pescadores de hombres". A través de este proceso, se habían convertido en mensajeros del reinado de Dios.

\section{Pablo y sus comunidades}

El bautismo "en el nombre de Jesús" (Hch 2,38; 8,16; 10,18; cf. 1Cor $1,15)$, surgido en los círculos judeocristianos palestinenses, fue el rito de iniciación característico de las primeras comunidades cristianas. L. Hartman ha estudiado esta práctica ritual, sin precedentes en el contexto de la tradición judía de la época romana, que era la forma de acceso a la iden-

13 La antropología social ha acuñado la expresión "rites de passage" (cf. GENNEP, Arnold van, Los ritos de paso, Taurus, Madrid 2008) para hacer referencia a todo cambio de un estado previo a otro posterior que puede ser ritualizado. Se suelen distinguir las transiciones cósmicas y las transiciones en la vida humana. Entre estas últimas, junto a los "ciclos vitales", se incluyen también los cambios de estatus social. 
tidad propia de los creyentes en Cristo ${ }^{14}$. La referencia lucana en Hch 11,26 del origen antioqueno del nombre griego "cristianos", aunque es una mención proveniente de un momento posterior del desarrollo del cristianismo primitivo, da una idea de lo que acontecía en las sinagogas de Antioquía -la tercera ciudad en importancia del imperio romano en este tiempo- hacia finales de los años 30 . El movimiento de Jesús ha adquirido una identidad propia tal que contrasta con los demás grupos judíos y por ello se les designa con otro nombre. Con bastante probabilidad se han incorporado ya no judíos (paganos y "temerosos de Dios") al grupo de los seguidores de Jesús. Aquel pasaje nos da también la noticia de que esta es la comunidad judeohelenista que, a través de Bernabé, acogerá al converso Pablo, tras su iniciación y bautismo en Damasco por Ananías, según el testimonio lucano (Hch 9,18; cf. Hch 22,16). En la comunidad de Antioquia se va desarrollar un nuevo sentido del baño bautismal al constituirse en signo de incorporación a la comunidad cristiana sin necesidad de recibir la circuncisión (cf. Hch 10,47-48) ${ }^{15}$.

En efecto, la creciente presencia de paganos, junto a los judíos, en las comunidades cristianas helenistas planteó un doble problema: intrajudío e intracristiano. El primero tenía que ver con el lugar de culto. Como frecuentaban las mismas sinagogas que los judíos, para evitar que los cristianos de origen pagano les contaminaran con su impureza, pronto las comunidades tuvieron que buscar sus propios lugares de reunión, separándose de la sinagoga (ca. 80 p.C). Las comunidades paulinas surgen ya fuera de las sinagogas y se congregarán en dos tipos de asambleas: domésticas (casas) y públicas ("de toda la comunidad")16. El problema intracristiano tenía que ver con el sentido de pertenencia. La identidad cristiana debía estar por encima del origen judío o no de sus miembros, lo que obligaba a relativizar las normas de pureza ritual ${ }^{17}$. Esta cuestión es la que se planteó en el trasfondo de la llamada asamblea de Jerusalén (cf. Gal 2,1-10; Hch 15,1-29). Allí el año 48 ó 49 parece que se llegó a un

14 Cf. Hartman, Lars, "Into the Name of the Lord Jesus": Baptism in the Early Church, T \& T Clark, Edinburgh 1997. "El rito característico a través del cual una persona se convertía en miembro de los primeros grupos cristianos era el "bautismo", una inmersión ritual que incluía la invocación del nombre de Jesús (Hch 2,28; 8,16; 10,18)" (HurTADO, Larry W., Señor Jesucristo. La devoción a Jesús en el primitivo cristianismo, Sígueme, Salamanca 2008, 175).

15 Cf. Dunn, James D.G., El cristianismo en sus comienzos. II. Comenzando desde Jerusalén, Verbo Divino, Estella 2012, 518-521; GıL, Carlos, "La primera generación fuera de Palestina", en Aguirre, Así empezó, 149.

16 Cf. Vouga, François, Los primeros pasos del cristianismo. Escritos, protagonistas, debates, Verbo Divino, Estella 2001, 131-140. Sobre la separación entre la Iglesia y la sinagoga, cf. Ib. 173-188.

${ }^{17}$ Es el fenómeno bautizado por J.D.G. Dunn como "The Parting of the ways". 
acuerdo de mínimos: no imponer la circuncisión a los paganocristianos, con lo que indirectamente se estaba legitimando también la misión a los gentiles. El posterior intento de mediación para resolver el conflicto de Antioquía (cf. Gal 2,11-14) no fue aceptado por Pablo en coherencia con su fe en la igualdad de todos los cristianos a los ojos de Dios, con independencia de su origen étnico o religioso. En consecuencia, a partir de este momento él va a iniciar su misión autónoma. Un brillante estudio de S. Vidal ha mostrado su evolución ${ }^{18}$.

Siguiendo su estrategia misionera (cf. Rm 15,20), desde Antioquía Pablo se desplazó hacia la capital del Imperio y desde ahí hacia Occidente por las vías romanas, estableciendo pequeñas comunidades en las principales ciudades ${ }^{19}$. Al ausentarse enviaba colaboradores y mantenía una correspondencia epistolar con ellas para mantener la vinculación y resolver los problemas. Cuando llegaba a una población se ponía a trabajar en su oficio de guarnicionero (cf. Hch 18,1-3) y desde esa plataforma laboral anunciaba el evangelio "de boca en boca" 20 a través de dos espacios preferentes: las asambleas o "ekklesías" locales y las casas. Quienes aceptaban la buena nueva, recibían el bautismo y formaban una pequeña comunidad doméstica en casa de un creyente (cf. Fil 1,2; 1Cor 16,19; Rm 16,5) y esas diversas comunidades nucleares se reunían periódicamente en la asamblea de toda la ciudad (cf. 1Cor 11,20;1Cor 14,23-24), probablemente en un local de alquiler ("scholae", "tabernaculae", "cenacula") donde se celebraba el culto ("Cena del Señor").

En las urbes grecorromanas en las que se implantaron las comunidades paulinas se encontraba una población multiétnica y multilingüística, desarraigada, procedente del campo y de los territorios conquistados. Tanto el culto oficial como las religiones mistéricas funcionaban como plataformas de resocialización generando un nuevo sentido de pertenencia y ofreciendo vínculos de identificación sociorreligiosa. Para ello se servían de ritos de iniciación característicos que buscaban la incorporación del candidato a un nuevo universo simbólico ${ }^{21}$. También las comunidades paulinas se presentan como una nueva familia en la que el neófito adquiere una nueva

\footnotetext{
18 Cf. VIDAL, Senén. El proyecto mesiánico de Pablo, Sígueme, Salamanca 2005.

19 Cf. Meeks, Wayne A., Los primeros cristianos urbanos, Sígueme, Salamanca $1988,131-183$.

${ }^{20}$ El polemista romano Celso (s. II) señala que los cristianos "hacen resonar" el evangelio de ese modo (cf. OríGEnEs, Contra Celso 3,55: cit. GiL, Carlos, "La primera generación", 168).

21 Cf. Stegemann, Ekkehard W. - W. Stegemann, Wolfgang, Historia social del cristianismo primitivo. Los inicios del cristianismo y las comunidades cristianas en el mundo mediterráneo, Verbo Divino, Estella 2001.
} 
identidad social. Un ejemplo de ese proceso de iniciación lo encontramos en Gal 3,26-4,6.

Ese texto paulino, que transmite una antigua fórmula bautismal (cf. 3,26-28), es un testimonio fehaciente del carácter iniciático del bautismo. La comunidad cristiana aparece como nueva familia. Por el rito bautismal se adquiere una nueva filiación como don de Dios Padre (cf. 4,6). La poderosa imagen de "revestirse de Cristo" (cf. 3,27) anula las diferencias de condición social, étnica o sexual (cf. 3,28). Podemos suponer que en las comunidades paulinas cubrir la desnudez del bautizado con un nuevo vestido simboliza cubrir ritualmente toda diferencia de clase, raza o género, mostrándose a los ojos de Dios -y en consecuencia a la vista de todos- con la dignidad de los hijos de Dios (cf. Gn 1,27). El don del Espíritu en el bautismo otorga una nueva identidad determinada por la pertenencia a una nueva familia. Si el rito realizaba su virtualidad propia, a partir del baño bautismal el neófito pertenecía a la comunidad cristiana con todas las consecuencias. El rito se administraba una sola vez por lo que Pablo va a recordar constantemente a sus comunidades su significado (cf. 1Cor 5,6-8; Gal 6,15; 2 Cor 5,17...) $)^{22}$.

El epistolario paulino refleja la preocupación de Pablo por mostrar las señas de identidad del neófito y las fronteras que delimitaban la pertenencia a la ekklesía. Una situación privilegiada por él para potenciar la identidad del grupo y afirmar sus fronteras son las comidas. Habían sido causa de ruptura en Antioquia tras la visita de Pedro (cf. Gal 2,11-14) y representaban el espacio comunión del que debían ser excluidos los comportamientos contra la comunidad -excomunión- (cf. 1Cor 5,11). De un modo singular la identidad de la comunidad está representada en la "Cena del Señor" (cf. 1Cor 11,17-34). A diferencia del bautismo que se celebraba una única vez como rito de incorporación a la comunidad, aquélla tenía la función de mantener viva la nueva condición adquirida con el bautismo. Esta comida cultual, según la tradición recibida por Pablo sin analogías con las comidas sagradas de otros grupos judíos del período romano, expresaba la comunión religiosa de los participantes con Jesucristo y entre sí, y constituía el centro de la vida litúrgica de los primeros grupos cristianos desde sus orígenes ${ }^{23}$.

Para describir la trasformación bautismal la teología paulina va a recurrir a imágenes de contraste: los dos Adanes, tinieblas-luz, carneespíritu, muerte-vida. El rito bautismal señala el paso de una situación

22 Cf. Pesce, Mauro - Destro, Adriana, Antropología delle origini cristiani, Laterza, Bari-Roma 1995, 111.

23 Cf. HurTAdo, Señor Jesucristo, 176-179. 
previa a otra nueva. El punto culminante de su exposición, en el contexto de su doctrina sobre la justificación, es Rm 6,1-1124.

En ese pasaje Pablo hace una novedosa lectura del bautismo en clave pascual, asociándolo con la muerte y resurrección de Cristo. Esa participación tiene como fruto una nueva vida en plenitud. El texto retoma la antigua expresión "en Cristo" (Gal 3,26.28) para reformularla ahora como "en la muerte de Cristo" (Rm 6,3-4; cf. 1Cor 4,8; 1Cor 15,13). El rito bautismal implica la participación en la muerte de Cristo. Morir con Cristo significa morir al pecado (cf. 6,2). Esta identificación total del creyente con Cristo por medio del bautismo explica la profusión de neologismos con el prefijo con- que recoge el pasaje ("con-sepultado", "conunido", "con-crucificado", "con-muerto"). Esta rica analogía paulina de la inmersión -en la tierra / en el agua- debe tener como fundamento la praxis ritual del bautismo, tal y como se desarrollaba ya en sus comunidades. La conexión del bautismo con la noción de morir y resucitar con Cristo no esta documentada con anterioridad a este pasaje. Representa una dramatización ritualizada en la que la inmersión en el agua bautismal simboliza la sepultura del hombre viejo y la emersión el nacimiento a una nueva vida.

Por otra parte, el texto ofrece un caso de lo que algunos autores consideran "transferencia ritual" (Kulturbetragung) ${ }^{25}$. En este sentido hay quien propone que $\mathrm{Rm} 6$ representaría para las comunidades paulinas -y para la primera generación cristiana- la etapa final de una evolución en la praxis bautismal originaria a partir de los baños judíos pasando por los ritos baptistas de conversión. Tras asumir el bautismo de Juan como precedente inmediato, el rito bautismal cristiano se va a redimensionar en el ámbito de las comunidades paulinas con referencia directa al acontecimiento pascual. No supondría ya una práctica penitencial o de conversión, sino un verdadero rito de iniciación. Según esta hipótesis, las dificultades en la comunidad de Corinto indujeron a Pablo a dotar al rito bautismal de incorporación a las comunidades de la gentilidad de una nueva configuración simbólica. La "transferencia ritual" explicaría la ausencia de referencias explícitas al modo de realizar al baño bautismal en el corpus paulino. Se trataría de un rito primordial en el mundo grecorromano comúnmente admitido -de forma semejante al symposium res-

\footnotetext{
${ }^{24} \mathrm{El}$ análisis del texto es el que ofrece el trabajo de ViVES Cuesta, Alfonso, "Cristianismo versus cultos mistéricos. Una lectura contextualizada del Bautismo en Rm 6", en Estudio Agustiniano 49 (2014) 275-341.

${ }^{25}$ La expresión "transferencia cultural" nace en el ambiente de la Escuela de historia de las religiones y fue introducida por E, Schmidt.
} 
pecto de la Cena del Señor ${ }^{26}$. Mientras la praxis ritual fue transferida sin modificaciones reseñables, en cambio, se hizo necesaria una nueva interpretación contextualizada.

\section{LA GENERACIÓN APOSTóLICA}

\section{La comunidad lucana}

Lucas escribe hacia el año 90 para una comunidad misionera mayoritariamente pagano-cristiana establecida en una ciudad importante del Imperio romano, quizás la misma capital27. Ante los romanos, respetuosos de lo ancestral, pretende mostrar el origen antiguo del cristianismo. Emplea ese mismo argumento frente a los judíos, pero en otro sentido: para mostrar que en la aparente novedad del cristianismo, en realidad, se cumplen las antiguas promesas del Dios de Israel. Según R. Aguirre, a esta comunidad se le plantean tres tipos de problemas principales: étnico, social y político ${ }^{28}$. El primero se cuestiona cómo integrar en una misma comunidad personas de procedencias y culturas tan diversas, incluso enfrentadas en la sociedad. El segundo plantea la incorporación a la comunidad cristiana de personas con recursos económicos y prestigio social. La tercera problemática tiene que ver con las relaciones del cristianismo con la autoridad imperial. Para responder a estas cuestiones la comunidad lucana no sólo recurre a la memoria de Jesús (Lc), también atiende las mociones del Espíritu (Hch).

$\mathrm{Al}$ principio la convivencia entre judíos y paganos dividió mucho a las comunidades nacientes. Los judaizantes no aceptaban incurrir en impureza compartiendo comensalía con los pagano-cristianos. Lucas narra los episodios de la asamblea de Jerusalén y del conflicto de Antioquia mostrando una clara tendencia redaccional a flexibilizar e integrar las posturas extremas. Así Pedro y Pablo alcanzan un compromiso que, por un lado, respeta la libertad de los cristianos no judíos al no imponerles la circuncisión, y por otro, hace ciertas concesiones al grupo judeocristiano de Santiago (cf. Hch 15,20.28-29) para no herir susceptibilidades.

26 Cf. Smith, Dennis E., Del Simposio a la Eucaristía. El banquete en el mundo cristiano antiguo, Verbo Divino, Estella 2009.

27 Ya Ireneo de Lyon ( $A d v$ Hae 3,1,1; 3,14,1) y Eusebio de Cesarea (HE II,22,6) afirman que Hechos fue escrito en Roma. Entre otros autores contemporáneos, G. Theissen también defiende esa localización para toda la obra lucana.

28 Para lo que sigue, cf. AGUiRRE, Rafael, "La segunda generación y la conservación de la memoria de Jesús: el surgimiento de los evangelios”, en Idem, Así empezó, 242-248. 
Lucas legitima esta postura ecléctica, en primer lugar, apelando a la actitud misericordiosa de Jesús en el evangelio (cf. Lc 15). Pero también la justifica como obra del Espíritu Santo. En efecto, es muy significativo en este sentido que, por ejemplo, según Hechos, el primer apóstol de los gentiles sea Pedro y no Pablo. Movido por el Espíritu y superando la barrera ("limen") de su propia mentalidad judía (cf. Hch 10,13-16.27-29; Hch 11,1-18), en Cesarea, Pedro "da el paso" de entrar -"cruzar el umbral"- en casa del centurión romano Cornelio, les anuncia el evangelio y bautiza (obviamente sin circuncisión previa) a todos los de la casa (cf. Hch 10,47-48).

Para la primera generación cristiana Pedro y Pablo representaban dos líneas diversas (judeocristiana y paganocristiana) del cristianismo primitivo. La obra lucana reconcilia y armoniza las trayectorias petrina y paulina. Comienza a construir un cristianismo integrador que cristalizará durante la segunda mitad del s. II en la "gran Iglesia". En la comunidad lucana, quizás por primera vez en el desarrollo inicial del cristianismo, ya no es problemática la convivencia entre cristianos provenientes del judaísmo y cristianos provenientes de la gentilidad.

Otro tema que se plantea la obra lucana es la cuestión de los bienes materiales en la vida cristiana. Lucas narra la conversión de personajes bien situados económicamente. Además de Cornelio, el centurión de Cesarea -al que ya nos hemos referido-, menciona a Lidia, una rica comerciante textil de Tiatira (cf. Hch 16), a un eunuco etíope anónimo, alto funcionario de la corte de la reina de Etiopía (cf. Hch 8) y a varias mujeres distinguidas que se convierten en Tesalónica y Berea por la predicación de Pablo (cf. Hch 17,4.12). Hay mucho material propio de L que se refiere al uso de las riquezas: las bienaventuranzas (cf. Lc 6,20.24), la exhortación a prevenirse de la codicia (cf. Lc 12,5) que precede a la parábola del rico insensato, las burlas de los fariseos "amigos de las riquezas" ante su enseñanza (cf. Lc 16,14) en el contexto de la parábola del rico y el pobre Lázaro. En la explicación de la parábola del sembrador solamente Lucas dice que las riquezas son un obstáculo para que la semilla de fruto (cf. Lc 8,14). Los sumarios de Hechos que presentan a la primitiva comunidad de Jerusalén subrayan la comunión de bienes (cf. Hch 2,44-45; 4,32.34-35). La avaricia es el pecado capital que destruye la fraternidad (cf. Hch 5,1-11) y la amenaza a sus intereses económicos es lo que amotina a los orfebres de Éfeso contra Pablo (cf. Hch 19,23-40).

Esos ejemplos ponen de relieve que la preocupación social de Lucas no reside tanto en la atención a los pobres de las comunidades, como en prevenir del peligro de las riquezas y exhortar a los cristianos acomodados a hacer un buen uso de sus bienes. En la parábola lucana del pobre 
Lázaro (Lc 16,19-31) el amor al dinero no es un pecado más, sino el pecado de idolatría, que sacrifica todo a ese ídolo, usurpando el lugar de Dios. Ciertamente el Jesús lucano subraya la predilección de Dios por los pobres y el necesario desprendimiento de los bienes, como condición del seguimiento, con más radicalidad que los otros sinópticos. Ahora bien, ese posicionamiento responde a la situación social del tiempo y, aunque no deje de presentarse como instancia crítica permanente, no se propone ya como un ideal a imitar en el tiempo de la Iglesia ${ }^{29}$.

La problemática política que está presente en la perspectiva lucana tiene que ver con la postura de las comunidades cristianas ante el imperio romano. Lucas mantiene el contraste de la alternativa cristiana, pero desde una posición realista que busca evitar en lo posible el conflicto. No se acomoda ni pacta con el sistema dominante, pero, al mismo tiempo, rehuye el enfrentamiento directo con el poder establecido. En este sentido no se pueden ocultar los motivos pro-romanos que aparecen en algunos textos lucanos. Por ejemplo, la insistencia con la que señala que el prefecto Poncio Pilato encuentra a Jesús inocente, a pesar de las tres graves acusaciones expresamente políticas que se vierten en su contra (cf. Lc 23,2). En Hechos Pablo exhibe con orgullo su ciudadanía romana (cf. Hch 16,35-38; Hch 22,25-29), una acreditación tradicional que hoy ha sido puesta en discusión ${ }^{30}$.

Aunque en la obra lucana -como en todo el NT- hay una evidente preocupación por el modo de articular la relación entre las comunidades cristianas y la autoridad política, de modo que el cristianismo sea respetado, la tesis de que la obra de Lucas es una apología pro-romana resulta infundada. Con el lenguaje críptico típico de todo grupo marginal (arcano), junto a pasajes que muestran una inequívoca condescendencia con las autoridades, en los textos lucanos hay otros abiertamente críticos con el poder imperial. El evangelio de la infancia (Lc 1-2) es un ejemplo de ello. La paz que trae Jesús (cf. Lc 1,79; 2,14), contrasta con la "pax roma$n a$ " conquistada a base de dominación y muerte. Para Lucas el "Hijo de Dios" y "Salvador" es Jesús y no el emperador Octavio Augusto. Lucas no sólo conserva la crítica a la teología imperial que estaba presente ya en la predicación de Jesús, sino que reivindica la "teología política" común a la tradición de la segunda generación cristiana.

${ }^{29}$ Se puede advertir si se comparan las exigencias de Jesús en Lc 9,3 con las de Lc 22,35-36, cuando está a punto de separarse de los discípulos. En este sentido es significativo que en el episodio lucano de la conversión de Zaqueo (Lc 19,1-11), prototipo de la conversión de un rico, aunque no deja de ser exigente, el neoconverso no lo deja todo, solamente la mitad de sus bienes (cf. Lc 3,11).

30 Cf. Álvarez, David, Pablo y el Imperio romano, Sígueme, Salamanca 2009. 


\section{Los discípulos del Bautista y la identidad de las comunidades joá- nicas}

Las tradiciones sobre Juan Bautista tienen una gran importancia en todos los evangelios. En el Cuarto evangelio (cf. Jn 1,19-51; 3,22-30) presentan unas características propias muy definidas como son: que Juan dé testimonio de la preexistencia de Jesús, una nota propia de la cristología joánica (cf. Jn 1,15); el hecho de que, también por su testimonio, algunos de sus discípulos pasaran al movimiento de Jesús (cf. Jn 1,35-40); y el esfuerzo por justificar la superioridad de Jesús sobre Juan, prueba de que se trataba de una cuestión objeto de controversia. Según R. Brown, la comunidad joánica, a pesar del conflicto que mantiene con otros seguidores de Juan Bautista (cf. Jn 1,20;3,28), trata de mostrar la continuidad de Jesús con el testimonio de Juan y lo cristianiza "hasta el punto de hacer hablar a éste como un cristiano joánico"31.

Por otra parte, el conflicto con la Sinagoga está también muy presente en los escritos de Jn. Los grupos joánicos compartieron el culto sinagogal con otros judíos por bastante tiempo. En varios pasajes los discípulos son amenazados con ser expulsados de la sinagoga por confesar a Jesús (cf. Jn 7,13; 9,22; 12,42;16,2). Es evidente el tono polémico del evangelio de Juan que se manifiesta en las constantes diatribas entre Jesús y "los judíos"32. Ello muestra que los grupos joánicos vivieron una situación muy tensa en las sinagogas que se fue haciendo insostenible. Su expulsión de la sinagoga fue un acontecimiento traumático ${ }^{33}$ que dejó una profunda huella en la vida de las comunidades. De todos modos, la salida de las sinagogas fue progresiva y no se produjo simultáneamente en todos los lugares. Por eso el enfrentamiento entre judíos y cristianos de Jn hay que explicarlo, sobre todo, en el contexto de la redefinición de la identidad judía a partir del año 70. La locución "los judíos", que aparece tantas veces en Jn, es una alusión -en tono irónico y polémico- a la identidad religiosa de los antagonistas de las comunidades joánicas. Por consiguien-

31 Brown, Raymond E., La comunidad del discípulo amado, Sígueme, Salamanca 1983, 31.

32 Esta expresión, tan frecuente en Jn, llevó a algunos a preconizar el carácter antijudío de este evangelio. Una acusación que se ha demostrado claramente gratuita y anacrónica: el propio Jesús, todos sus discípulos y muchos de los integrantes de los grupos joánicos eran judíos. El apelativo se usó también en el norte, e incluso fuera de Palestina para designar a aquellos grupos que mantenían una estrecha relación con Jerusalén y su Templo.

33 "Pero tuvo el sentido del trauma del nacimiento a una nueva existencia, ya que fue entonces cuando tuvieron que configurarse como nuevas comunidades separadas ya de las prácticas del judaísmo" (VIDAL, Senén, Los escritos originales de la comunidad del discípulo amigo de Jesús. El evangelio y las cartas de Juan, Sígueme, Salamanca 1997, 23). 
te, "no es tanto un apelativo étnico cuanto una identidad religiosa" 34 . Este debate sobre la condición judía se planteó con virulencia en las sinagogas que frecuentaban los grupos joánicos. Resulta llamativo que esos grupos se apropien de las tradiciones judías patriarcales (Abraham, Jacob), del Éxodo (Moisés) e incluso de la creación, pero que nunca recurran a la tradición davídica. Frente a una memoria restauracionista del pasado, las comunidades joánicas proponen una relectura de la historia de Israel y de la esperanza mesiánica iluminadas desde Jesús. Al apropiarse del pasado de esa forma concreta y en confrontación con la memoria de otros grupos judíos, los grupos joánicos fueron definiendo su propia identidad. Por los rastros que quedan en el evangelio se puede suponer que ese conflicto dejó cicatrices muy profundas, pero posibilitó, a la vez, una identidad propia muy contrastada, con la cristología como elemento clave.

Además del culto sinagogal, los grupos joánicos celebraban otras reuniones, pero no en las casas como otras comunidades cristianas. A diferencia de Pablo y los Sinópticos, Juan no parece tener la casa como lugar de reunión de la comunidad, lo que no quiere decir que no tuvieran sus propios espacios separados. Algunos datos confirman esa tesis. Siempre que aparece el contexto de una comida, el evangelio de Juan nunca menciona que tuviera lugar en una casa ${ }^{35}$. El vocabulario doméstico característico está prácticamente ausente. Como han mostrado algunos yacimientos arqueológicos, junto al lugar del culto, en el recinto de las sinagogas había también otros espacios. Es probable que los grupos joánicos emplearan esos locales adyacentes de las sinagogas para las comidas rituales (¿eucaristías?).

El rito de iniciación básico de las comunidades joánicas es el bautismo, derivado de la actuación de Juan Bautista y de las prácticas de sus discípulos, pero que la comunidad cristiana realiza ahora en nombre de Jesús. Por el agua bautismal se ingresaba en la comunidad que se congregaba en su nombre y era el "sello" que garantizaba la salvación definitiva, que los grupos joánicos también creían muy cercana ${ }^{36}$. Llama la atención que la expresión "Reino de Dios" (Jn 3,3b.5) aparezca únicamente en el diálogo de Jesús con Nicodemo, precisamente para presentar el sentido iniciático del bautismo como un "renacimiento".

\footnotetext{
34 Bernabé, Carmen, "Las comunidades joánicas: un largo recorrido en dos generaciones", en Aguirre, Así empezó, 320.

35 La única casa que aparece en Jn es la de Betania. Ni en las bodas de Caná ni en la última cena se dice que las comidas se desarrollen en una "casa", aunque los textos de las traducciones bíblicas sí lo hagan.

36 Cf. VIDAL, Los escritos originales, 43.
} 
Muy importante era también la reunión periódica de la comunidad -probablemente semanal-. Un rasgo característico de las comunidades joánicas es la modificación de la tradición de la última cena. Siempre en el contexto social del banquete comunitario (symposium), mientras que muchas comunidades cristianas tomaron el gesto de Jesús sobre el pan y el vino como elemento central de su memorial de la Pascua, las comunidades joánicas conservaron el gesto del lavatorio de los pies, gesto de amor y de servicio, en recuerdo de la última cena. En la relectura final del evangelio, la introducción del mandato de repetir el gesto (cf. Jn 13,14-15) hace todavía más evidente que el gesto del lavatorio sustituye al del pan y la copa de vino de las otras tradiciones. La elección del nuevo gesto supone una revisión de la tradición anterior por parte de la comunidad que pone de relieve el servicio y la fraternidad. También en ese pasaje la figura del discípulo amado se manifiesta en contraste con la de Pedro: el primero de los apóstoles tiene que recurrir a aquél para llegar a Jesús (cf. Jn 13,24).

Parece claro que los grupos joánicos - como las comunidades paulinas- se acercaron a los "temerosos de Dios", sobre todo a partir del momento en que las relaciones con otros judíos de la sinagoga comenzaron a empeorar. El malentendido a propósito de la huída de Jesús a un destino secreto (cf. Jn 7,35) está reflejando seguramente, con la típica "ironía joánica", la apertura del grupo a la gentilidad de la diáspora. En una situación crítica también con el imperio romano, el evangelio da orientaciones a los cristianos de cómo vivir en tales circunstancias, sin claudicar ante la ideología imperial, a pesar de las consecuencias que esa actitud pudiera acarrear.

\section{La tradición postpaulina}

El contexto social de las llamadas cartas de la cautividad (Colosenses y Efesios) es de abierta hostilidad hacia las comunidades cristianas por parte del poder imperial (finales s. I - comienzos s. II). Un factor importante de esa hostilidad fue, sin duda, la postura de los cristianos frente al culto al emperador ${ }^{37}$. La oposición fue creciendo hasta dar lugar a las persecuciones de los primeros siglos del cristianismo. Los escritos deuteropaulinos (Col, Ef y 2Tes) transmiten en sus textos esa oposición cristiana al culto imperial, poniendo la figura salvadora del Mesías cruci-

37 Cf. Álvarez, David, "El cristianismo en el imperio romano (ss. I-II)”, en AguiRRE, Así empezó, 397-399. 
ficado en contraste con el emperador romano. Por otra parte, las comunidades paulinas en este período tenían una viva conciencia de su misión universal y en consecuencia una actitud de apertura al entorno sociocultural. Esto se acentuaba con el incremento del número de cristianos provenientes de la gentilidad. A finales del s. I los grupos paulinos están compuestos mayoritariamente por miembros de origen pagano. En esas circunstancias era normal que las prácticas sociales y religiosas de ese entorno influyeran en las de los grupos cristianos. En el "proceso de institucionalización" de las comunidades paulinas, junto a los campos organizativo y ético, esa influencia tuvo su repercusión también en el campo de la ritualidad religiosa ${ }^{38}$.

Aunque es muy difícil identificar a los "oponentes" contra los cuales se dirigen las cartas deuteropaulinas (especialmente $\mathrm{Col}$ ) parece que se trataba de algunos que pretendían introducir ciertas "tradiciones de hombres" frente a la "tradición según Cristo" $(\mathrm{Col} 2,8)$. Por los datos que ofrece el autor de esta carta (cf. Col 2,16-23) podemos suponer que se trataba de ciertos "hombres sagrados" que se presentaban como intermediarios de la divinidad y pretendían introducir elementos iniciáticos ascéticos y sapienciales consistentes en una serie de prácticas o cultos esotéricos: banquetes, ritos de luna nueva, el sábado, cultos angélicos, visiones, rituales ascéticos... Para contrarrestar esas "amenazas", las comunidades paulinas se ven forzadas a ampliar su universo simbólico. Pablo había afirmado ya que la circuncisión real no es la hecha en el cuerpo y había presentado a los cristianos como verdaderos circuncisos (cf. Rm 2,28-29; Flp 3,3). Ahora en Col 2,9-13 el bautismo se pone por encima de los "elementos del mundo" y se presenta expresamente como una circuncisión no humana, "circuncisión de Cristo". Es el rito de incorporación al pueblo de la nueva alianza establecida con la muerte y resurrección de Cristo. Sustituye definitivamente a la circuncisión externa, corporal, quirúrgica.

Seguramente la reelaboración de la imagen del cuerpo (Ef 1,20-23 cf. 1Cor 12,22-24.27) sea uno de los ejemplos más elocuentes de la evolución doctrinal del paulinismo. Tanto Pablo como los autores de Colosenses y Efesios en la segunda generación emplean la misma imagen para presentar a la ekklesía. Sin embargo, mientras para el primero todos los creyentes forman la totalidad del cuerpo de Cristo, para los segundos Cristo es ahora la cabeza (cf. Col 2,18-19; Ef 4,4.15) y los demás son los miembros (cf. Ef 3,6; Ef 4,24; Ef 5,30). Es patente la evolución de un modelo eclesiológico más horizontal a otro más vertical ${ }^{39}$.

\footnotetext{
38 Cf. VIDAL, Senén, Colosenses y Efesios, Verbo Divino, Estella 2013, 18-20.

39 Cf. GiL, Carlos, "El desarrollo de la tradición paulina", en Aguirre, Así empezó, 279-285.
} 
En conclusión, hay que considerar el desarrollo de la tradición paulina como un eslabón determinante del proceso de consolidación de las creencias y las prácticas rituales fundamentales del cristianismo naciente en camino hacia la confluencia en la "gran Iglesia" en la segunda mitad del s. II.

\section{TESTIMONIOS EXTRACANóNICOS}

\section{Los ritos de iniciación cristiana en la Didajé}

Durante la segunda generación cristiana, además de la mayoría de los escritos del NT, surgieron también otros textos relevantes que figuran, incluso, en algunas listas de los libros canónicos, y que recogen lo que posteriormente se considerarán tradiciones ortodoxas. El más antiguo de ellos es el escrito de un autor anónimo denominado Didajé o "Doctrina de los apóstoles" 40 . Está dirigido a una comunidad judeocristiana de lengua griega, por lo que hoy se piensa que, probablemente, fue compuesto en Antioquia para resolver los conflictos de la comunidad tras la partida de Pablo.

La Didajé aborda detalladamente diversas temáticas, morales, litúrgicas y disciplinares, de la vida de la comunidad agrupadas en cuatro secciones. Aparentemente las dos primeras secciones, catequética (cc. 1-6) y litúrgica (cc.7-10), contienen una amalgama de instrucciones inconexas sobre la catequesis, el bautismo, el ayuno y la eucaristía. Sin embargo, están proponiendo un modelo articulado de iniciación cristiana para los gentiles convertidos dentro de una comunidad judeocristiana ${ }^{41}$. El análisis de los textos permite reconstruir un proceso iniciático en las tres fases características de los ritos de paso (ruptura, margen y agregación). En efecto, la enseñanza de "los dos caminos" de la primera sección propone los elementos típicos de las fases pre-liminar y liminar; mientras que la sección siguiente sobre el bautismo y la comida eucarística contiene el material propio de los ritos post-liminares de incorporación al grupo.

En continuidad con el judaísmo, la doctrina de la Didajé exige a los gentiles optar por "el camino de la vida" (cf. 1,2-4,14) como requisito pre-

40 Se considera que la Didajé es el escrito cristiano no canónico más antiguo, anterior incluso a algunos libros del NT. Algunos estudios recientes lo datan en la segunda mitad del s. I, incluso antes que Mt. Para una breve presentación en contexto, cf. ÁlvAREZ, David, "La Didajé en el proceso formativo del cristianismo", en AgUIRre, Así empezó, 343-357.

41 Cf. Draper, John William, "Ritual Process and Ritual Symbol in Didache 7-10", en Vigiliae Christianae 54 (1999) 1-38. 
vio para ser admitido al bautismo y para compartir, después, la mesa eucarística (cf. 7,1; 9,5). Es claro que esta parénesis inicial tiene como finalidad la ruptura con la anterior condición social pagana del converso. La sección litúrgica de la Didajé propone la última fase del proceso de iniciación cristiana. El ritual de agregación comienza con la exigencia del ayuno y la oración, prácticas comunes de cualquier judío piadoso. El ayuno ritual de los catecúmenos, de quien los va a bautizar y de otros que quieran unirse libremente dura uno o dos días (cf. 7,4). Después tiene lugar el baño ritual en "agua viva", por inmersión o infusión, y el pronunciamiento solemne del nombre de las personas de la Trinidad sobre cada bautizado $^{42}$. Es la primera descripción documentada del rito del bautismo cristiano ${ }^{43}$. Tras el bautismo se recita la oración dominical (padrenuestro), que deberá repetirse tres veces al día (cf. 8,3), como signo de pertenencia a la comunidad. Además se rescata el agrapha: "No deis lo santo a los perros" $(9,5)$ para recordar que solamente los bautizados pueden acceder a la eucaristía.

Fuertemente influida por las prácticas de comensalía judía, la Didajé concluye el ritual de iniciación con una comida sagrada (cf. 9,1-4) ${ }^{44}$ y una larga oración de acción de gracias. Antes de la comida encontramos una acción de gracias sobre el cáliz (cf. 9,2) y otra sobre el pan partido (cf. 9,3), a la que sigue una súplica por la Iglesia (cf. 9,4); y, después de la comida, la plegaria (cf. 10,2-6). Seguramente refleja una fase intermedia entre la tradición judía de las bendiciones de mesa y la eucaristía cristia$n a^{45}$. Esta secuencia de instrucción, ayuno, bautismo, oración y eucaristía, aunque ensombrecida por la inserción de otros elementos redaccionales, constituye el itinerario básico del proceso de iniciación cristiana.

42 Sobre el discutido origen de la fórmula trinitaria que transmite, cf. AguiRre, Rafael, "El bautismo en las primeras comunidades cristianas", en La santísima Trinidad y el bautismo cristiano, Secretariado Trinitario, Salamanca 1992, 64.

43 Didajé 7,1-3: "En cuanto al bautismo, bautizad de esta manera: una vez expuestas todas estas cosas bautizad [sumergiendo] en agua viva en el nombre del Padre y del Hijo y del Espíritu santo [1]. Si no tienes agua viva bautiza con otra agua; si no puedes con agua fría, con agua caliente [2]. Si ambas te faltan, derrama agua tres veces en la cabeza, en el nombre del Padre y del Hijo y del Espíritu santo [3]".

${ }^{44}$ Llama la atención el contraste de esta versión con las tradiciones evangélicas de la Cena. En todo caso, sobre el trasfondo de las comidas rituales judías (haburáh), la precedencia de la acción de gracias sobre el cáliz parece sugerir mayor proximidad a la tradición antioquena (cf. 1Cor 11,23-25; Lc 22, 15-20) que a la palestinense. Cf. SCHWIEBERT, Jonathan, Knowledge and the coming of the Kingdom. The Didache's Meal Ritual and his Place in Early Christianity, T \& T Clark, London-New York 2008, 148-182.

45 Hay una gran semejanza entre la oración final y las bendiciones judías que precedían a la comida (qiddush) o la acción de gracias conclusiva (birkat ha-mazon). Cf. RIVAs, Fernando, "El nacimiento de la gran Iglesia", en Aguirre, Así empezó, 438-439. 
La finalidad de la obra del "didajista" es doble. En primer lugar, la socialización de los gentiles y dotarles de una identidad nueva dentro de la comunidad cristiana. Y por otra parte, definir la identidad propia de su comunidad frente a los judíos de la sinagoga mediante ritos propios (bautismo, eucaristía) y cambios en las prácticas comunes (distintos días de ayuno, contenido de la oración). Pero la comunidad de la Didajé aparece profundamente enraizada en el judaísmo. Todavía no hay rastro de la separación de la sinagoga que dará lugar posteriormente, en la segunda mitad del s. II, al nacimiento de dos religiones diversas.

\section{Otros textos cristianos de la segunda y tercera generación}

La carta a los Corintios (1Clem), atribuida tradicionalmente a Clemente de Roma, es otro de los libros incluido en el canon del NT por algunos manuscritos antiguos (hasta el s. XI). Se trata de un texto de origen judeocristiano (casi la cuarta parte de la obra son citas del AT), compuesto entre finales del s. I y la primera década del II, que pretende devolver la concordia interna a la comunidad cristiana de Corinto. Además de su influjo en la cuestión de la sucesión apostólica, fue una obra muy utilizada en el culto cristiano hasta comienzos del s. IV. Precisamente refiriéndose a la labor de los apóstoles como continuadores de la obra de Cristo, se recuerda que fueron estableciendo ministerios (epískopos y diáconos) mientras "pregonaban por ciudades y lugares la buena nueva y bautizaban a los que obedecían el designio de Dios" (1Clem 42,1). Tenemos aquí un testimonio implícito de los ministerios originarios de la praxis bautismal en las comunidades de la segunda generación cristiana.

Para Ignacio de Antioquia -obispo martirizado hacia el 110-, siguiendo la tradición paulina, el bautismo se funda en la pasión de Cristo: "Él fue bautizado para que pudiera purificar el agua del bautismo mediante su pasión" (IgnEf 18,2). La conversión previa que requería implicaba la renuncia a muchas prácticas paganas socialmente admitidas. El baño bautismal era el rito de ingreso en una comunidad escatológica guiada por el Espíritu. El impresionante testimonio de su disposición al martirio es un ejemplo elocuente de lo que más tarde la tradición llamará "bautismo de sangre": la comprensión de la muerte como paso ("parto") a un nuevo nacimiento ${ }^{46}$. Desde el punto de vista de la identidad cristiana

46 "Escribo a todas las Iglesias y les dejo bien claro que voy de buen grado a morir por Dios, si es que vosotros no lo impedís. Os ruego que no tengáis conmigo una benevolencia inoportuna. Dejadme ser pasto de las bestias, por las que podré alcanzar a Dios. Trigo soy de Dios y he de ser molido por los dientes de las bestias para que resulte puro 
resulta destacable que el sustantivo "cristianismo", para distinguirlo del judaísmo, se emplea por primera vez con Ignacio de Antioquia ${ }^{47}$. Con él se va a imponer también el nombre de "eucaristía" sobre otros términos (cena, partición del pan) para designar a la comida ritual cristiana.

Hacia la mitad del s. II, Justino, también mártir y el principal apologista cristiano del s. II, en la I Apología (ca. 153-155) ofrece el testimonio de una sencilla ritualización bautismal en un momento en que el cristianismo está en la fase de incipiente institucionalización. En la comunidad de Roma la preparación al bautismo constaba de dos etapas. La primera, de preparación penitencial, estaba dedicada a la instrucción de los conversos y tenía como elementos básicos el alejamiento del pecado y el aprendizaje del bien. Las prácticas tradicionales del ayuno y la oración aparecen conectadas con la preparación bautismal48. En la segunda, de asimilación doctrinal y moral, se le pedía al candidato no sólo el conocimiento de las verdades de la fe (credo), sino también un comportamiento acorde con la enseñanza recibida. Según refiere detalladamente Justino, el "catecúmeno" era sometido a prueba tanto por el catequista que lo acompañaba -que ejercía de maestro de iniciación-, como por la propia comunidad que lo encaminaba hasta la fuente bautismal para recibir el baño de regeneración o "iluminación"49. También este autor atestigua la invocación trinitaria: el agua se recibía en el nombre de Dios Padre, de Jesucristo y del Espíritu Santo. El rito concluía con la eucaristía, culmen del proceso de iniciación cristiana ${ }^{50}$, a la que podían participar solamente

pan de Cristo... para mí, mejor es morir en Jesucristo que ser rey de los términos de la tierra. A Aquél quiero que murió por nosotros. A Aquél quiero que por nosotros resucitó. Y mi parto es ya inminente... No me impidáis vivir; no os empeñéis en que yo muera... Dejadme contemplar la luz pura. Llegado allí, seré de verdad hombre" (Carta a los Romanos 4,$1 ; 6,1-2)$.

47 Cf. A los Magnesios 10,1-3; A los Filadelfios 6,1; A los Romanos 3,3 (cit. F. RIvas, "El nacimiento de la "gran Iglesia" en Así empezó el cristianismo, 427). Corresponde al nombre "cristianos" que ya aparecía por vez primera también en Antioquia según Hch 11,26 .

48 "A cuantos se convencen y creen que son verdaderas estas cosas que nosotros enseñamos y decimos, y prometen poder vivir conforme a ellas, se les instruye ante todo para que oren y pidan, con ayunos, perdón a Dios de sus pecados anteriormente cometidos, y nosotros oramos y ayunamos juntamente con ellos" (I Apología 61,2).

49 "Luego los conducimos a un sitio donde hay agua, y por el mismo modo de regeneración con que nosotros fuimos también regenerados, son regenerados ellos, pues entonces toman en el agua el baño en el nombre de Dios, Padre y Soberano del universo, y de nuestro Salvador Jesucristo y del Espíritu Santo... A este baño se le llama iluminación, para dar a entender que son iluminados los que aprenden estas cosas" (I Apología 61,3.10.12-13).

50 "Por nuestra parte, nosotros, después de así lavado el que ha creído y se ha adherido a nosotros, le llevamos a los que se llaman hermanos, allí donde están reunidos, con 
los bautizados ${ }^{51}$. Muy verosímilmente en este tiempo el escenario de la acogida de los neófitos ("iluminados") era la reunión dominical. La celebración de los ritos del bautismo y la eucaristía durante la vigilia pascual presuponen la organización del catecumenado antiguo, que funcionará sólo a partir del s. III ${ }^{52}$.

\section{Reacciones paganas frente a los ritos cristianos}

Los ritos de iniciación del cristianismo provocaron en el s. II una fuerte reacción de oposición por parte de las autoridades romanas, pero, sobre todo, de hostilidad de las masas populares. Porque en realidad fue esta última la que precedió y, en muchos casos, originó aquella oposición gubernamental. Ambas derivaban de las graves acusaciones estereotipadas dirigidas contra los cristianos. A menudo los rituales del culto cristiano fueron considerados impíos e inmorales, interpretados como ritos mágicos y prácticas supersticiosas. Así, se explican las acusaciones de ateísmo (negativa a dar culto a los dioses, ausencia de los ritos oficiales), magia (canto de himnos, glosolalia, signo de la cruz, exorcismos...), de antropofagia o canibalismo (eucaristía), de relaciones incestuosas (uso del lenguaje familiar: "amor" "hermano/a", ósculo de la paz...), de clandestinidad o pertenencia a sociedades secretas (reuniones nocturnas, disciplina del arcano en el proceso de iniciación), etc. En fin, como resume D. Álvarez, a finales del s. II el nombre de "cristiano" se había convertido

el fin de elevar fervorosamente oraciones en común por nosotros mismos, por el que acaba de ser iluminado y por todos los otros esparcidos por todo el mundo, suplicando se nos conceda, ya que hemos conocido la verdad, ser hallados por nuestra obras hombres de buena conducta y guardadores de lo que se nos ha mandado, y consigamos así la salvación eterna. Terminadas las oraciones, nos damos mutuamente el ósculo de la paz. Luego, al que preside a los hermanos, se le ofrece pan y un vaso de agua y vino, y tomándolos él tributa alabanzas y gloria al Padre del universo por el nombre de su Hijo y por el Espíritu Santo, y pronuncia una larga acción de gracias, por habernos concedido esos dones que de Él nos vienen. Y cuando el presidente ha terminado las oraciones y la acción de gracias, todo el pueblo presente aclama diciendo: 'Amén'. 'Amén' que en hebreo quiere decir 'así sea'. Y una vez que el presidente ha dado gracias y aclamado todo el pueblo, los que entre nosotros se llaman 'ministros' o diáconos, dan a cada uno de los asistentes parte del pan y del vino y del agua sobre la que se dijo la acción de gracias y lo llevan a los ausentes" ( $I$ Apología 65,1-5). Sobre la eucaristía, cf. 66,3; 67,1-7.

51 "Y este alimento se llama entre nosotros 'eucaristía', de la que a nadie es lícito participar, sino al que cree ser verdaderas nuestras enseñanzas y se ha lavado en el baño que da la remisión de los pecados y la regeneración, y vive conforme a lo que Cristo nos enseñó" (I Apología 66,1).

52 Hamman, Adalbert G., La vida cotidiana de los primeros cristianos. Un apasionante viaje por nuestras raíces (=Arcaduz 37), Palabra, Madrid7 2002, 220-221. 
en el calificativo para identificar toda forma de conducta o actividad antisocial ${ }^{33}$. Esa animosidad y hasta violencia de la plebe contra los cristianos se explica tanto por el conocimiento superficial y erróneo de las creencias y prácticas cristianas, como por la búsqueda de un "chivo expiatorio" (R. Girard) en un grupo extraño que se percibía como una amenaza para los valores tradicionales y las estructuras identitarias de la sociedad. En una sociedad sacral como la romana la persecución contra los cristianos supuso una especie de catarsis colectiva. La reacción anticristiana, tanto popular como "ilustrada", adoptó formas diferentes, desde las burlas despectivas, hasta las más abiertas agresiones.

La correspondencia de Plinio el Joven, legado imperial en BitiniaPonto (111-113), con el emperador Trajano constituye una importante fuente de información sobre las denuncias vertidas contra los cristianos. A pesar de no mostrar ningún interés por conocer el cristianismo y en contra de sus sospechas, lo cierto es que encuentra los ritos cristianos totalmente inocuos. En particular destaca la legalidad de sus comidas (cf. Carta X,96,7), lo que prueba que tenía noticia de la usual acusación de canibalismo que circulaba contra los cristianos. Informa de dos tipos de reuniones: una por la mañana, con himnos a Cristo como Dios (¿eucaristía?) y otra para una cena "ordinaria e inofensiva" (¿ágape?). Esta misma fuente, al hacer referencia a dos esclavas diaconisas ${ }^{54}$, confirma indirectamente el carácter inclusivo de la incorporación a las comunidades cristianas, sin diferencias de clase social, estatus, etnia o sexo.

Dentro del ambiente hostil descrito, a diferencia de la oposición popular, la obra de los apologistas anticristianos tuvo como objetivo aportar argumentos razonados contra las doctrinas y prácticas cristianas, buscando demostrar que el cristianismo era una perversa superstitio irracional e insensata. Es el caso de los filósofos estoicos Epicteto (50-130) y el emperador romano Marco Aurelio. Éste último en su obra Meditaciones (ca.156) considera a los cristianos unos fanáticos insensatos y contrapone la "teatralidad" del mártir cristiano a la compostura serena del filósofo ante la muerte. En la misma línea, el pagano Luciano de Samosata, en su opúsculo satírico Sobre la muerte de Peregrino (167), considera a

53 Cf. Justino, I Apología 1,26; Diálogo con Trifón 10,1; Minucio Félix, Octavio 8,4-5; 9,2-5; Tertuliano, Apologeticum 7,1; Atenágoras, Legatio pro cristianos, 3,1; Actas de Pablo y Tecla, 15.20; Plinio el Jóven, Cartas 10,96 (cit. Álvarez, David, "El cristianismo", 407). En este apartado seguimos el completo estudio de ese autor (Ib. 379-426).

54 "Esto me convenció de que era necesario encontrar la verdad por todos los medios, incluso con la tortura de dos esclavas [ancillae] que llamaban diaconisas [ministrae], Pero no llegué a descubrir más que una superstición irracional y desmesurada [superstitio prava et immodica]" (Plinio, Cartas X, 96-97, cit. EstÉveZ, Elisa, "Las mujeres en los orígenes cristianos", en Aguirre, Así empezó, 547). 
los cristianos unos "pobres estúpidos" que adoran a un "filósofo crucificado" y viven según sus preceptos. Respecto a los ritos cristianos, para Luciano el cristianismo es un "nuevo culto mistérico".

El pensador romano Marco Cornelio Frontón (ca. 100-166) es uno de los más despiadados contra los cristianos. Destaca por su crítica -transmitida por una obra de Minucio Félix- de las prácticas de la nueva doctrina: "por medio de reuniones nocturnas, de ayunos frecuentes y de alimentos indignos del ser humano, sellan una alianza no mediante una ceremonia sagrada, sino sacrílega; gente que busca el secreto y huye de la luz, muda en público y charlatana en los rincones..." (Octavio 8,4)55. Según Frontón, los cristianos eran un grupo depravado, de gente corrupta, que en sus "ceremonias secretas y nocturnas" daban rienda suelta a todo tipo de perversiones. Este autor asume, sin contraste alguno, los rumores aireados por la plebe y atribuidos a los cristianos -también contra los judíos- sobre bacanales y banquetes tiesteos (infanticidios seguidos de comensalía caníbal) propios de los cultos de las religiones orientales. La lista de acusaciones es larga: nunca se encuentran en público ni participan en los espectáculos de la ciudad, en sus reuniones nocturnas celebran una comida ritual inhumana, usan distintivos secretos, mantienen relaciones incestuosas, realizan prácticas libidinosas y orgiásticas.

También el filósofo pagano Celso, en su Discurso verdadero (177180) -del que tenemos noticia a través de Orígenes-, refuta el cristianismo, pero dejando al margen los rumores difundidos entre las masas ${ }^{56}$. Llama la atención que no mencione ya los tópicos clásicos de la crítica popular contra los cristianos (canibalismo, incesto, infanticidio, orgías...). En su crítica, Celso considera el cristianismo una secta nueva, indigente y aberrante, que ha apostatado del judaísmo (Contra Celso V,33). Sus miembros proceden de los estratos sociales más bajos y sus líderes seducen a la gente inculta (cf. Ib. III,44; 55). Desde el punto de vista político, es una peligrosa sociedad secreta que favorece la sedición. Religiosamente, defienden que hay un solo Dios, sin embargo dan culto a un Crucificado. Propugnan la intolerancia con los demás cultos y aspiran a convertirse en la única religión verdadera.

Probablemente el célebre médico Galeno de Pérgamo representa una excepción en el tono general de las reacciones paganas ante el cristianismo. Su toma de posición resulta doblemente original. Por un lado sorprende el respeto, incluso cierta simpatía, que muestra hacia los cris-

55 Minucio Félix, Octavio (Biblioteca Patrística 52), Madrid 2000, 66-67.

56 Cf. FERnÁndez, Samuel, "El Discurso verídico de Celso contra los cristianos. Críticas de un pagano del siglo II a la credibilidad del cristianismo", en Teología y vida 45 (2004) 238-257. 
tianos por su coraje y sentido de la justicia. Entre los autores paganos sobresale en su esfuerzo por liberarse de prejuicios para tratar de comprender el cristianismo. Le atrae la fuerza moral que sostiene el valor de los cristianos. Por otro lado, considera el cristianismo una "filosofía" elemental, adaptada a un grupo de carácter popular. Lo destacable de esta apreciación es que, situando a los incultos cristianos como una filosofía moral o práctica, a mediados del s. II, Galeno introduce un cambio radical en la visión tradicional del cristianismo. Los cristianos dejan de ser unos abominables conspiradores contra el imperio romano para convertirse en seguidores de una "escuela".

En síntesis, los ritos cristianos de iniciación aparecen a los ojos de la población y de la literatura pagana de la época como un culto de origen oriental que incluía prácticas secretas -impías e inmorales- de tipo mistérico. Hacia finales del s. II, la visión pagana del cristianismo se fue desplazando progresivamente de la antipatía inicial contra los cristianos, basada en infundadas acusaciones populares, hacia la crítica propia de los sistemas filosóficos que cuestionaban la irracionalidad de sus doctrinas (encarnación, resurrección) y de sus prácticas religiosas. En esta situación, junto al testimonio apocalíptico de los mártires (Ap, Pastor de Hermas) y a la respuesta apologética de la "corriente profética" (Justino, Carta a Diogneto), van a aparecer las corrientes gnósticas. Éstas evitarán todo comportamiento social anómalo, los conflictos con las autoridades y tenderán a recluir el culto cristiano en la esfera privada.

\section{Conclusión}

Debido a la escasez de las fuentes no podemos conocer al detalle los ritos que se desarrollaban para agregar nuevos miembros a las comunidades cristianas durante los dos primeros siglos. Sin embargo, desde sus inicios el baño de agua (rito de ingreso) y la comida sagrada (rito de pertenencia) adquieren en ellas un valor central, combinando equilibradamente elementos tradicionales (provenientes de la tradición judía) y otros nuevos (a partir de los contextos locales). A diferencia de las sinagogas, que podían disponer de varios lugares de culto y reunión en la misma ciudad, los primeros grupos cristianos solían reunirse en un único escenario comunitario, al que los nuevos miembros accedían tras la conversión y el bautismo, y al que quedaban vinculados por una serie de ritos, especialmente por la celebración eucarística dominical.

Teniendo como referente la praxis iniciada con el movimiento de Jesús, un momento decisivo en la configuración ritual del cristianismo 
primitivo está representado por la adopción del baño bautismal practicado por Juan. La primera generación cristiana va a conectar ahora su valor escatológico con la Pascua ("paso") de Jesús, dotándolo así de un sentido propiamente iniciático. De este modo, el bautismo y la efusión del Espíritu harán innecesario el antiguo rito judío de la circuncisión, todavía presente en las comunidades judaizantes palestinenses.

El proceso de iniciación cristiana mantendrá como elementos fijos el baño bautismal y la oración y el ayuno que lo preparaban. Pero se va a desarrollar con una gran variedad de expresiones dependientes tanto del diverso origen de los grupos cristianos, como de la pluralidad de contextos culturales. Al no existir todavía una instancia legitimada para regular litúrgicamente ese proceso, serán ciertas comunidades con una especial influencia, debida a su origen apostólico, a su historia, a su vitalidad o su importancia numérica (Jerusalén, Antioquía, Roma) las que ejercerán esa función. Ya al final del período apostólico pero, sobre todo, desde mediados del s. II, está documentado un proceso ritual que comenzaba con la conversión, continuaba con un período de maduración en la fe y en la vida cristiana y culminaba con el rito del bautismo, antes de la agregación del neófito a la comunidad eclesial mediante la participación plena en la eucaristía. Es importante destacar la presencia constante de toda la comunidad a lo largo del proceso. Participa activamente no sólo con la oración y el ayuno, sino también en la selección e instrucción de los candidatos y acompañándolos al recibir el bautismo.

El creciente distanciamiento del judaísmo, la mayor apertura al influjo cultural y religioso del mundo grecorromano y, sobre todo, la consolidación de la identidad cristiana a lo largo de la cuarta generación cristiana son los factores que posibilitarán la organización de la praxis de la iniciación cristiana que desembocará en la institución del catecumenado antiguo en los albores del s. III. 